\title{
Fine-grained Fiber Concrete on Mechanoactivated Portlandcement
}

\author{
Vorokhaiev Anatolii \\ Odessa State Academy of Civil Engineering \& Architecture \\ Barabash Ivan \\ Odessa State Academy of Civil Engineering \& Architecture \\ Ksonshkevych Liubov \\ Odessa State Academy of Civil Engineering \& Architecture \\ Kos Zeljko \\ University North \\ Grynyova Iryna \\ Odessa State Academy of Civil Engineering \& Architecture
}

\begin{abstract}
This article is devoted to the study of the mechanical properties of fine-grained concrete used for flooring in industrial and civil buildings. Characterized by the well-known advantages (unlimited raw material base, manufacturability, high homogeneity), finegrained concrete requires an increased consumption of cement to achieve the necessary mechanical characteristics - compressive strength, abrasion, impact resistance. An alternative to the known technological method is proposed an intensive separate technology (IST) for preparing fine-grained concrete mixtures using a high-speed mixeractivator in the presence of hydrophobized basalt fiber and a polycarboxylate superplasticizer Relaxol-Super PC. The use of IST leads to an increase in the strength of finegrained concrete in compression by 1.9 times, impact resistance by a factor of 2, and a decrease in abrasion by 40 ... 50\% in comparison with the control. The relevance of using the technology of monolithic floors for industrial and civil construction is due to a wide range of varieties of Portland cement, the grain composition of aggregates, as well as the simplicity of the technology for preparing a fine-grained concrete mixture.
\end{abstract}

Key words: intensive separate technology, basalt fiber, abrasion, impact resistance, activated binder.

Paper type: Research article

Received: 6.1.2021.

Accepted: 24.1.2021.

DOI: $10.2478 /$ crdj-2021-0007 


\section{Introduction}

The floors of industrial and civil buildings are constantly exposed to all kinds of loads that arise during their operation. The accumulated experience shows that, in terms of technological features, one of the most effective materials for flooring is fine-grained concrete [1]. The factors that hinder the widespread introduction of fine-grained concrete into construction practice are its higher cost compared to ordinary concrete, as well as relatively low mechanical characteristics: compressive strength, wear resistance, shock resistance [2]. A significant reserve for improving the mechanical characteristics of finegrained concrete is its dispersed reinforcement, as well as the mechanical activation of Portland cement due to the use of high-speed mixers in the technology of preparing concrete mixtures [3-7]. It has been established that the introduction of basalt fiber into a fine-grained concrete mixture leads to a decrease in its mobility, which requires an increase in the amount of mixing water [8-10]. In addition, there are technological difficulties to ensure a uniform distribution of fiber in the volume of the mixture. The negative influence of the above factors can be radically reduced due to the hydrophobization of the basalt fiber.

\section{Methodology}

The aim of the study is to improve the mechanical characteristics of fine-grained concrete through the use of intensive separate technology (IST) for preparing a concrete with polycarboxylate superplasticizer Relaxol-Super PC and hydrophobized basalt fiber.

The objective of the research is to study the effect of prescription factors on the mechanical characteristics of fine-grained concrete on activated Portland cement.

Portland cement grade 500 PC II / A-Sh-500 produced by Cement LLP (Odessa) with a content of ground blast furnace slag of $18 \%$ was used in the studies. The specific surface area of the cement was $350 \mathrm{~m}^{2} / \mathrm{kg}$. Quartz sand of the Nikitsky quarry (Nikolaev area) with $M c=2.4$, as well as washed screening of granite crushed stone with a fraction of $2.5 \pm 5$ $\mathrm{mm}$, was used as a fine aggregate. The bulk density of the screenings was $1610 \mathrm{~kg} / \mathrm{m}^{3}$, the content of dusty particles did not exceed $0.6 \%$. Granite crushed stone of $5 \pm 10 \mathrm{~mm}$ fraction was used as a large aggregate. Crushed stone met the requirements of DSTU BV.2.7-75-98 "Crushed stone and dense natural gravel for building materials, products, structures and works".

The polycarboxylate superplasticizer Relaxol-Super PC (Budindustriya, Zaporozhye) was used to increase the mobility of the concrete mixture. Basalt fiber Bauson-basalt $12 \mathrm{~mm}$ long and $18 \pm 2 \mu \mathrm{m}$ in diameter was used as a fibrous filler. The hydrophobic properties of basalt fibers were imparted by treating them with the silicon-organic liquid GKZh-10, followed by drying at $\mathrm{T}=105 \pm 110^{\circ} \mathrm{C}$.

The concrete mix was prepared using intensive separate technology. For this, the dosed amounts of Portland cement, water and superplasticizer were loaded into a high-speed mixer $(V=2800 \mathrm{r} / \mathrm{min})$, where the binder was activated for 180 seconds. The freshly prepared suspension was mixed with dosed amounts of basalt fiber, quartz sand, granite screening and granite crushed stone in an ordinary (slow-speed) mixer.

The mobility of the fine-grained concrete mixture at each point of the mathematical plan was corrected by the amount of mixing water and was within $16 \pm 1 \mathrm{~cm}$ shrinking of the 
Abrams cone. The hardening of samples of fine-grained concrete took place under normal conditions in a chamber with a temperature of $20 \pm 2{ }^{\circ} \mathrm{C}$ and a relative humidity of at least $95 \%$.

The compressive strength of fine-grained concrete was determined by testing the halves of the samples - beams $4 \times 4 \times 16 \mathrm{~cm}$ in size at the age of 28 days.

The abrasion of the investigated fine-grained concrete was determined by testing cube specimens with an edge of $7.07 \mathrm{~cm}$ on an LKI-3 device in accordance with the procedure set forth in DSTU B.V.2.7-212: 2009 "Building materials. Concrete. Methods for determining abrasion ".

The impact resistance of fine-grained concrete was determined from the results of testing cubic specimens with an edge of $7.07 \mathrm{~cm}$ on a vertical dynamic laboratory test machine. The value of the impact resistance of concrete was determined by the equation:

$$
T\left(\mathrm{~J} / \mathrm{cm}^{2}\right)=P \times \sum_{1}^{N} h \times \frac{N}{S}
$$

where $\mathrm{P}$ - is the mass of the striker, $\mathrm{kg}$;

$\mathrm{h}$ - is the height of the falling weight, $\mathrm{m}$;

$\mathrm{N}$ - is the number of blows before the destruction of the sample, $\mathrm{n}$;

$\mathrm{S}$ - is the area through which the load was transferred, $\mathrm{cm}^{2}$.

\section{Results}

Study of the mechanical properties of concrete was produced by testing two similar series of samples: the first (index "a") - using mechanical activation of cement in a triboactivator and the other, control (index "c") - using traditional technology. This made it possible to compare the properties of concretes of similar compositions, but prepared using different technologies - intensive separate and traditional. For this purpose, a 25-point 4-factor plan was used, in which the following factors of the composition of fine-grained concrete were varied: $\quad X_{1}$ - the amount of Portland cement $\left(400 \pm 100 \mathrm{~kg} / \mathrm{m}^{3}\right) ; X_{2}$ - the amount of hydrophobized basalt fiber, $1 \pm 1 \mathrm{~kg} / \mathrm{m}^{3} ; X_{3}$ - the amount of granite sifting in granite crushed stone of fraction $5 \pm 10 \mathrm{~mm}$, in a mixture $\left(30 \pm 30 \% \mathrm{~kg} / \mathrm{m}^{3}\right) ; X_{4}$ is the amount of RelaxolSuper PC superplasticizer ( $1 \pm 0.4 \%$ of the cement mass).

The experimental data of the compressive strength, abrasion and impact resistance of finegrained concrete at 25 experimental points of the plan are given in Table 1. 
Table 1

Compressive strength of concrete, abrasion and impact resistance of the investigated finegrained concrete at the age of 28 days of normal hardening

\begin{tabular}{|c|c|c|c|c|c|c|c|c|c|c|}
\hline \multirow[t]{2}{*}{ № } & \multicolumn{4}{|c|}{$\begin{array}{l}\text { Variation } \\
\text { levels }\end{array}$} & \multicolumn{2}{|c|}{$\begin{array}{c}\text { Compressive } \\
\text { strength } \\
f_{\text {ck.cube }}(\mathrm{MPa})\end{array}$} & \multicolumn{2}{|c|}{$\begin{array}{l}\text { Abrasion, } \\
G_{1}\left(g / \mathbf{c m}^{2}\right)\end{array}$} & \multicolumn{2}{|c|}{$\begin{array}{l}\text { Impact resistance, } \\
\quad T\left(\mathrm{~J} / \mathrm{cm}^{2}\right)\end{array}$} \\
\hline & $X_{1}$ & $X_{2}$ & $X_{3}$ & $X_{4}$ & control & activation & control & activation & control & activation \\
\hline 1 & 1 & 1 & 1 & 1 & 50.1 & 53.8 & 0.19 & 0.18 & 16.8 & 17.1 \\
\hline 2 & 1 & 1 & 1 & -1 & 45.4 & 48.5 & 0.21 & 0.21 & 16.5 & 16.6 \\
\hline 3 & 1 & 1 & -1 & 1 & 47.2 & 49.7 & 0.20 & 0.20 & 16.2 & 16.4 \\
\hline 4 & 1 & 1 & -1 & -1 & 42.5 & 45.2 & 0.21 & 0.22 & 15.7 & 16.0 \\
\hline 5 & 1 & -1 & 1 & 1 & 49.3 & 52.7 & 0.27 & 0.26 & 9.7 & 9.8 \\
\hline 6 & 1 & -1 & 1 & -1 & 44.6 & 47.4 & 0.29 & 0.29 & 9.1 & 9.4 \\
\hline 7 & 1 & -1 & -1 & 1 & 46.3 & 49.1 & 0.27 & 0.28 & 7.7 & 8.2 \\
\hline 8 & 1 & -1 & -1 & -1 & 41.7 & 44.7 & 0.30 & 0.29 & 7.4 & 7.4 \\
\hline 9 & -1 & 1 & 1 & 1 & 37.7 & 40.2 & 0.23 & 0.22 & 12.4 & 12.7 \\
\hline 10 & -1 & 1 & 1 & -1 & 32.6 & 34.7 & 0.25 & 0.25 & 11.0 & 10.9 \\
\hline 11 & -1 & 1 & -1 & 1 & 34.5 & 36.1 & 0.23 & 0.22 & 11.1 & 11.3 \\
\hline 12 & -1 & 1 & -1 & -1 & 29.6 & 31.6 & 0.26 & 0.26 & 10.2 & 10.4 \\
\hline 13 & -1 & -1 & 1 & 1 & 36.7 & 38.9 & 0.29 & 0.28 & 6.7 & 6.6 \\
\hline 14 & -1 & -1 & 1 & -1 & 31.7 & 34.4 & 0.31 & 0.30 & 6.0 & 6.4 \\
\hline 15 & -1 & -1 & -1 & 1 & 33.6 & 36.6 & 0.31 & 0.29 & 5.9 & 6.1 \\
\hline 16 & -1 & -1 & -1 & -1 & 28.7 & 30.3 & 0.32 & 0.31 & 4.9 & 5.4 \\
\hline 17 & 1 & 0 & 0 & 0 & 49.1 & 51.1 & 0.21 & 0.20 & 13.4 & 13.5 \\
\hline 18 & -1 & 0 & 0 & 0 & 36.3 & 40.2 & 0.24 & 0.23 & 11.8 & 12.3 \\
\hline 19 & 0 & 1 & 0 & 0 & 43.9 & 47.2 & 0.21 & 0.19 & 14.4 & 15.0 \\
\hline 20 & 0 & -1 & 0 & 0 & 43.1 & 44.5 & 0.27 & 0.26 & 9.2 & 10.1 \\
\hline 21 & 0 & 0 & 1 & 0 & 44.2 & 45.7 & 0.22 & 0.21 & 13.2 & 13.5 \\
\hline 22 & 0 & 0 & 0 & 1 & 44.4 & 46.8 & 0.21 & 0.20 & 13.1 & 13.2 \\
\hline 23 & 0 & 0 & -1 & 0 & 41.7 & 46.4 & 0.21 & 0.20 & 12.9 & 12.8 \\
\hline 24 & 0 & 0 & 0 & -1 & 39.5 & 43.3 & 0.23 & 0.23 & 12.5 & 12.6 \\
\hline 25 & 0 & 0 & 0 & 0 & 44.0 & 47.5 & 0.22 & 0.20 & 12.7 & 13.0 \\
\hline
\end{tabular}

The influence of variable factors of the concrete composition on the value of its compressive strength (for concretes with an activated binder and prepared according to traditional technology) is described by the following ES-models:

$f_{\text {ck. cube }} a(M P a)=47.0+6.6 X_{1}-1.2 X_{1}^{2}$

$$
\begin{aligned}
& +0.5 X_{2}-1.0 X_{2}^{2} \\
& +1.5 X_{3}-0.8 X_{3}^{2} \\
& +2.4 X_{4}-1.8 X_{4}^{2}
\end{aligned}
$$

$f_{\text {ck.cube }} C(M P a)=43.9+6.4 X_{1}-1.1 X_{1}^{2}-0.1 X_{1} X_{2}-0.1 X_{1} X_{3}$ 


$$
\begin{aligned}
& +0.4 X_{2}-0.4 X_{2}^{2} \\
& +1.5 X_{3}-0.9 X_{3}^{2} \\
& +2.4 X_{4}-1.9 X_{4}^{2}
\end{aligned}
$$

The fields of models (1), (2) show the minimum values of concrete strength in compression (respectively $\mathrm{f}_{\text {ck.cubeamin }}=31.1 \mathrm{MPa}$ and $\mathrm{f}_{\mathrm{ck} . \text { cube }} \mathrm{C}_{\min }=28.7 \mathrm{MPa}$ ) at points with the same coordinates $X 1=X 2=X 3=X 4=-1$. The maximum value of concrete strength for the composition on activated cement $\left(f_{c k . c u b e} a_{\max }=53.9 \mathrm{MPa}\right)$ is achieved at the point with coordinates $\mathrm{X} 1=1 ; \mathrm{X} 2=0.34 ; \mathrm{X} 3=\mathrm{X} 4=0.9$. For concrete, the mixture of which was prepared according to the traditional technology, the maximum strength value ( $50.5 \mathrm{MPa})$ is achieved at the point with coordinates $\mathrm{X} 1=1 ; \mathrm{X} 2=0.52 ; \mathrm{X} 3=\mathrm{X} 4=0.98$. The combined one-factor diagrams, which were constructed using ES-models (1), (2) and reflecting the influence of variable composition factors on the value of concrete compressive strength, are shown in Fig. 1.

Figure 1

Influence of variable composition factors on concrete compressive strength in min and max zones

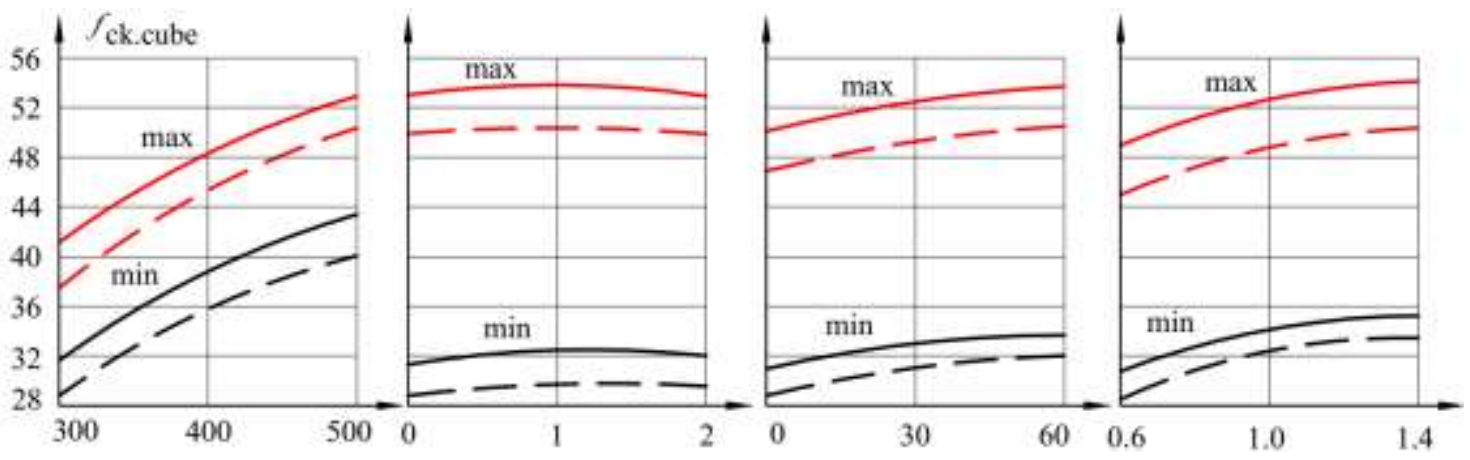

Cement, $\mathrm{kg} / \mathrm{m}^{3} \quad$ Fiber, \% Screenings, $\mathrm{kg} / \mathrm{m}^{3} \quad$ Relaxol-Super PC, \%

- - mixtures on activated cement;

- - - - - mixtures prepared using traditional technology

\section{Source: Author's illustration}

Analysis of experimental data indicates that at the age of 28 days the compressive strength of concrete on an activated binder is 2.5 ... 3.5 MPa higher than the strength of concretes of similar composition, prepared using traditional technology. It should be noted that the amount of basalt fiber slightly increases the strength of concrete, which is consistent with the research results [3-5]. Using the experimental data shown in table 1, ES-models of the fine-grained concrete composition variables influence on its abrasion were built:

$$
\begin{array}{rlr}
\mathrm{G}_{1 .} \mathrm{a}\left(\mathrm{g} / \mathrm{cm}^{2}\right)=0.202 & -0.013 \mathrm{X}_{1}+0.014 \mathrm{X}_{1}^{2}-0.005 \mathrm{X}_{1} \mathrm{X}_{2} & \\
& -0.034 \mathrm{X}_{2}+0.024 \mathrm{X}_{2}^{2} & -0.003 \mathrm{X}_{2} \mathrm{X}_{4} \\
& -0.004 \mathrm{X}_{3} & \\
& -0.013 \mathrm{X}_{4}+0.014 \mathrm{X}_{4}^{2} &
\end{array}
$$




$$
\begin{aligned}
\mathrm{G}_{1 .} \mathrm{C}\left(\mathrm{g} / \mathrm{cm}^{2}\right)=0.215 & -0.016 \mathrm{X}_{1}+0.011 \mathrm{X}_{1}^{2}-0.004 \mathrm{X}_{1} \mathrm{X}_{2} \\
- & 0.036 \mathrm{X}_{2}+0.026 \mathrm{X}_{2}^{2} \\
- & 0.003 \mathrm{X}_{3} \\
- & 0.010 \mathrm{X}_{4}+0.006 \mathrm{X}_{4}^{2}
\end{aligned}
$$

According to the data of ES-models (3) and (4) the minimum value of abrasion $\mathrm{G}_{1} \mathrm{a}_{\min }=$ $0.177 \mathrm{~g} / \mathrm{cm}^{2}$ and $G_{1} \cdot C_{\min }=0.188 \mathrm{~g} / \mathrm{cm}^{2}$ have compositions at points with coordinates: $X_{1}=X_{2}$ $=0.8 ; X_{3}=1 ; X_{4}=0.6$. In physical terms, concretes with the amount of cement and fiber close to the maximum, with a dropout content of $60 \mathrm{~kg} / \mathrm{m}^{3}$ and the additive Relaxol - Super $P C=1.2 \%$, are characterized by the minimum abrasion.

\section{Figure 2}

Influence of varied composition factors on the impact resistance of the concretes under study in the min and max zones

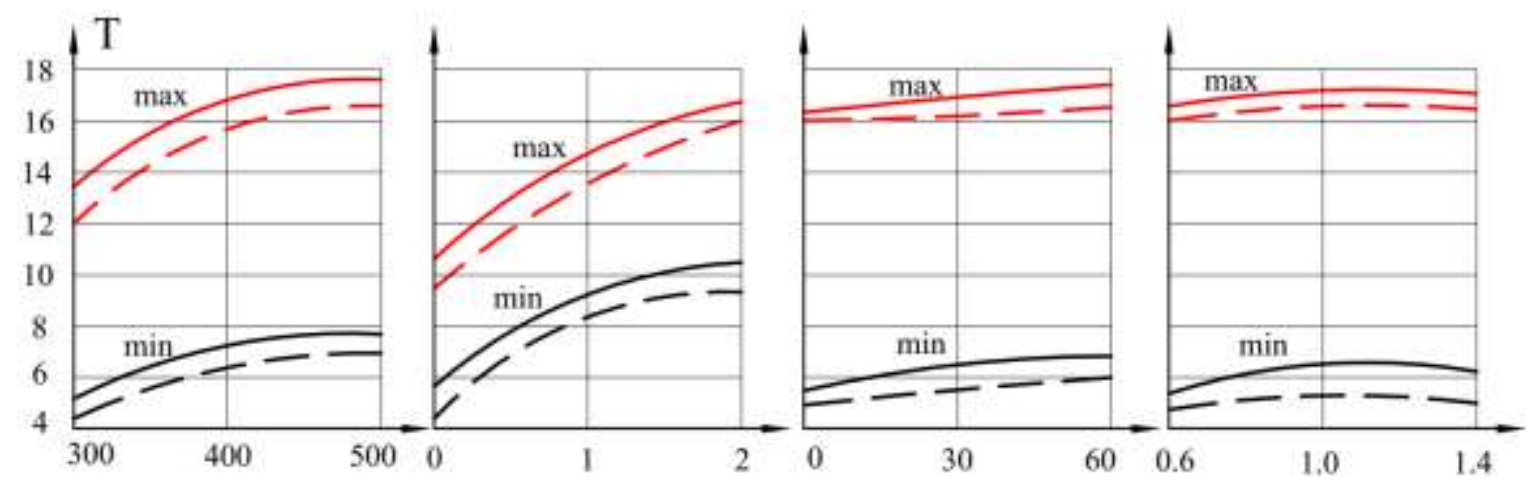

$$
\begin{array}{ll}
\text { Cement, } \mathrm{kg} / \mathrm{m}^{3} & \text { Fiber, \% } \quad \text { Screenings, } \mathrm{kg} / \mathrm{m}^{3} \quad \text { Relaxo } \\
\hline-{ }_{---} & \text {- mixtures with activated cement; }
\end{array}
$$

\section{Source: Author's illustration}

The maximum value of abrasion $G_{1} a_{\max }=0.309 \mathrm{~g} / \mathrm{cm}^{2}$ and $G_{1} \cdot C_{\max }=0.319 \mathrm{~g} / \mathrm{cm}^{2}$ have concrete compositions at points with the same coordinates $X_{1}=X_{2}=X_{3}=X_{4}=-1$. Such compositions are characterized by the minimum amount of cement $\left(400 \mathrm{~kg} / \mathrm{m}^{3}\right)$ and waterreducing additive $(0.6 \%)$.

Fiber and granite screenings are absent in such compositions. It should be noted that of all the factors under study, the amount of basalt fiber has the greatest influence on the abrasion of concrete - an increase in its content from 0 to $1 \%$ leads to a decrease in abrasion by an average of $25 . . .30 \%$. Concretes based on activated cement are characterized by less abrasion compared to the control, by an average of $8 \ldots 11 \%$.

Using the experimental data given in Table 1, combined one-factor diagrams were constructed, reflecting the effect of variable composition factors on the impact resistance of the concretes under study in the extremum zones, Fig. 2. 
Analysis of the data presented in diagrams shown on Fig. 2. allow us to conclude that the greatest influence on the impact resistance of concrete is the amount of dispersed reinforcement in it. Due to the introduction of hydrophobized basalt fiber, the impact resistance of concrete can be almost doubled. An increase in the impact resistance of concrete was noted due to an increase in the consumption of cement in concrete from 13 $\mathrm{J} / \mathrm{cm}^{2}\left(\mathrm{C}=300 \mathrm{~kg} / \mathrm{m}^{3}\right)$ to $17.0 \mathrm{~J} / \mathrm{cm}^{2}\left(\mathrm{C}=500 \mathrm{~kg} / \mathrm{m}^{3}\right)$, that is, by almost $25 \%$. additives for the impact resistance of concrete is insignificant and does not exceed 1 ... $3 \%$.

\section{Discussion}

Mechanochemical methods of activating mineral binders play an important role in improving the mechanical characteristics of building composites. The high-speed mixeractivator used in the work, creates turbulent flows in the process of mixing and promotes the activation of the surface layer of cement grains with the removal of part of the products of neoplasms in the dispersion medium. The exposing surface of cement grains in the process of rapid mixing promotes further hydration, while increasing the amount of neoplasm products and, consequently, intensifies the structure formation of the hardening system.

The results of experimental studies convincingly testify to the positive effect of Portland cement activation on the mechanical properties of fine-grained fiber concrete. The effect of mechanical activation on the mechanical characteristics of fiber concrete is especially effective in combination with the superplasticizer Relaxol - Super PC. By controlling the modes of mechanical activation and the formulation of the activated fine mixture, it is possible to control a wide range of mechanical properties of fine-grained fiber concrete.

\section{Conclusion}

1. The greatest influence on the strength of fine-grained fiber-reinforced concrete under compression at the age of 28 days is exerted by the amount of Portland cement in it. An increase in the dosage of a binder from 300 to $500 \mathrm{~kg} \mathrm{/m}$ increases the strength of concrete by $12 \ldots 12.5 \mathrm{MPa}$ for activated compositions and by $11.5 \ldots 12 \mathrm{MPa}$ for concrete whose binder has not been mechanically activated. Introduction to the mixture of granite screening in the amount of $40 \ldots 50 \mathrm{~kg} / \mathrm{m}^{3}$ leads to an increase in the strength of concrete by $3 \ldots 4$ $\mathrm{MPa}$.

2. Increase of the dosage of Relaxol-Super PC to $1.2 \ldots 1.4 \%$ increases the strength of concrete by $4 \ldots 6 \mathrm{MPa}$. The amount of basalt fiber does not significantly affect the compressive strength of concrete.

3. The use of dispersed reinforcement in combination with mechanical activation of cement leads to a decrease of the abrasion of fiber-reinforced concrete by 40 ... 50\%.

4. With the introduction of $2 \mathrm{~kg} / \mathrm{m}^{3}$ of fiber into the composition of the concrete mixture, abrasion decreases by 36 ... 48\% in comparison with the control, and the impact resistance of concrete on mechanically activated binder increases by about $50 \%$. 
5. The analysis of the resistance of fine-grained concrete at the brand age to abrasion and dynamic influences has shown the effectiveness of using cement activation and the use of hydrophobized basalt fiber.

\section{References}

[1] Zarubina L.P. (2011) Floor arrangement. Materials and technologies: St. Petersburg BHV Petersburg.

[2] Klyuev S.V. Lesovik R.V., A.V. Ginzbrurg, S.A. Kazlitin (2013) Fibrer concrete for heavy-load floors of industrial buildings. Belgorod: Publishing house of BSTU im. V.G. Shukhov.

[3] Barabash I., Harashenko D. (2018) Mechanoactivation of Portland cement in the technology of manufacturing the self-compacting concrete. Eastern-european journal of enterprise technologies. № 3/6 (93), 12-17

[4] Ksonshkevych L., Krantovska O., Petrov M., Synii S., Uhl A. (2018). Investigation of the structure of cement stone, obtaining and optimization of high-strength concrete on mechanically activated binder. MATEC Web of Conferences (pp. 1-8). EDP Sciences https://doi.org/10.1051/matecconf/201823003010

[5] Ksonshkevych L., Barabash I., Krantovska O., Synii S., Sunak P. (2019) Disperse reinforced concrete with polycarboxylate additive on a mechanically activated binder: IOP Conference Series: Materials Science and Engineering №708. IOP Publishing Ltd https://iopscience.iop.org/article/10.1088/1757-899X/708/1/012092

[6] Sobol, K., Blikharskyy, Z., Petrovska, N., \& Terlyha, V. (2014). Analysis of structure formation peculiarities during hydration of oil-well cement with zeolitic tuff and metakaolin additives. Chemistry \& Chemical Technology, 8, № 4, 461-466.

[7] Kharchenko, Ye V., et al. (2018). Study of Structural Changes in a Nickel Oxide Containing Anode Material During Reduction and Oxidation at $600^{\circ} \mathrm{C}$. In: International Conference on Nanotechnology and Nanomaterials (pp. 595-604). Springer, Cham.

[8] Sherbina O.S., Barabash I.V., Ksonshkevych L. (2016) Claydite-concrete on mechanically activated portland cement with the addition of basalt fiber. Wschodnioeuropejskie Czasopismo Naukowe (East European Scientific Journal) Warsaw, Poland №5, 66-71.

[9] Okamura H., Ouchi M. (2003) Self-Compacting Concrete. Journal of Advanced Concrete Technology, 1 (1), 5-15.

[10] Kuch H., Palzer S. (2005) Selbstverdichtender Beton zur Herstellung von Betonwaren und - fertigteilen. Beton. 1, 10-12.

\section{About the authors}

Vorokhaiev Anatolii, Engineer, Odessa State Academy of Civil Engineering and Architecture. The topic of scientific interests is related to building materials science, the search for mechanisms for accelerating the hardening of mortars. He is a member of the Supervisory 
Council at the Odessa State Academy of Civil Engineering and Architecture. The author can be contacted at voroxaev@gmail.com

Barabash Ivan, Doctor of Technical Sciences, Professor, Odessa State Academy of Civil Engineering and Architecture. The topic of his scientific interests is related to the mechanical activation of mineral binders. On this topic in 2005 he defended his doctoral dissertation "Concretes on mechanically activated mineral binders". He is a regular participant in international conferences and siminars on building materials science. The author can be contacted at dekansti@ukr.net

Ksonshkevych Liubov, PhD, Assistant Professor, Odessa State Academy of Civil Engineering and Architecture. She received a PhD in Odessa State Academy of Civil Engineering and Architecture with the dissertation thesis "High-strength concrete on the mechanically activated binder". Her research interests are in materials science. She is continuously participating in workshops and training related to education and research. The author can be contacted atwlksms@gmail.com

Kos Zeljko, PhD, Associate professor at the department of Civil Engineering, University North. Area of scientific interest: building materials, finite element method, load-bearing capacity, damaged reinforced concrete column, mathematical analysis, geotechnics and particularly energy efficiency. Owner of mandates on the base of state: Energy efficiency certifier, Occupational safety expert, Coordinator of occupational safety in civil engineering, Forensic expert in the field of civil engineering, Real estate assessment. He is actively engaged in number of EU funded projects and continuously participating in workshops and training related to edutation and research. The author can be contacted at zeljko.kos@unin.hr.

Grynyova Iryna, PhD in Technical Sciences, Senior Lecturer of the department of Architecture Structures, Odesa State Academy of Civil Engineering \& Architecture. Laureate of the scholarship of the Cabinet of Ministers of Ukraine for young scientists. Area of scientific interest: finite element method, load-bearing capacity. The author can be contacted at Irene.grinyova@gmail.com 